\title{
Rise and Fall of Decentralized School Governance-Decision-Making Practices in Georgia
}

\author{
Sophia Gorgodze ${ }^{1}$ \\ ${ }^{1}$ School of Education, Ilia State University, Tbilisi, Georgia \\ Correspondence: Sophia Gorgodze, School of Education, Ilia State University, 3/5 Cholokashvili Avenue, 0162, \\ Tbilisi, Georgia. Tel: 995-577-574-525. E-mail: sopho_gorgodze@iliauni.edu.ge
}

Received: May 12, 2016

doi:10.5539/ies.v9n11p25
Accepted: June 15, $2016 \quad$ Online Published: October 26, 2016

URL: http://dx.doi.org/10.5539/ies.v9n11p25

\begin{abstract}
The current study investigates educational decision-making in the former Soviet Republic of Georgia. The focus is on decisions concerning issues of school governance decentralization/recentralization in the period of 2003-2012. The research draws on in-depth interviews with over 20 top decision-makers, and an extensive review of legal documents, relevant research and media reports to gain a better understanding of decision-making practices in a newly democratized state. Two theoretical foundations are employed: the Multiple Streams model of decision-making and Electoral Connection. The research largely supports the Multiple Streams theory and expands the theory of Electoral Connection to fit the political setting of a post-soviet state. Among other findings, the research shows that decisions concerning school governance recentralization were primarily election-driven.
\end{abstract}

Keywords: decentralization, decision-making, electoral connection, election-driven, multiple streams, school governance

\section{Introduction}

The literature on educational policymaking in the post-soviet space is scarce, with a number of exceptions in the field of policy borrowing and diffusion (Steiner-Khamsi, 2005; Steiner-Khamsi, Silova, \& Johnson, 2006; Silova, 2009, 2012; Rivera, 2004; Janashia, 2015). Given the history of a more rational model of decision-making which solely favored party priorities and action through "democratic centralism" (Rudman, 1964), patterns of educational decision-making in post-Soviet countries are interesting.

This research explores educational decision-making in Georgia, and specifically decisions on school governance decentralization and recentralization in the period of 2003-2012. For the purposes of this study, school governance decentralization means school financial and administrative autonomy as defined by the Law of Georgia on General Education (2005). Recentralization, on the other hand, indicates a decrease in school autonomy, increased control and oversight of school administration and finances by the Ministry of Education, restriction of the School Board's rights, control over the school communications with media and other stakeholders, and removal of school autonomy over curriculum and textbook choice among other issues.

This policy change is important to explore, because with the same political administration, education policy swung from decentralization back to centralization (recentralization). Existing theories on policy borrowing and how policymakers use international experience to introduce and implement new policies (Philips \& Ochs, 2003) are unable to guide us in explaining this sudden turnaround. A better understanding of this particular policy change in Georgia can help us understand some of the important domestic factors that bring about policy change in post-soviet states.

In 2003, following the Rose Revolution, Georgia launched system-wide educational reform. One feature of this reform was decentralized school governance. The reform led to the establishment of schools as legal entities of public law and the provision of schools with real estate and bank accounts (Note 1). This allowed them to independently manage their finances (Shapiro, Nakata, Chakhaia, \& Zhvania, 2007). The school self-governance concept was introduced, which created school boards, teachers' councils, student self-governance, and disciplinary and appellate committees (Law on Georgia on General Education, 2005). The creation of School Boards of Trustees was a novelty which encouraged school autonomy and governance decentralization. 
Legislation in 2005 defined the School Board as a representative body of school self-governance consisting of teachers, parents and a student. It became responsible for, among other things, the election and/or dismissal of the principal and approval of the budget. Schools were freed from financial and administrative dependence on local government (Janashia, 2015).

Shortly after the launch of the decentralization policy implementation in 2006, school autonomy began to decrease and the Ministry of Education introduced numerous amendments to the education law which tied the hands of school administrations, in many ways making them dependent on the Ministry (Mshvenieradze, 2011).

Although educational decentralization is an interesting phenomenon, in this study I am not concerned by the ills or benefits of school governance decentralization, or its multifaceted forms, best practices or failed reforms, on which, there is an abundance of literature (Carnoy \& Hannaway, 1993; Hanson, 1997; Hanson, 2000; McGinn \& Welsh, 1999; Janashia \& Gorgodze, 2013; Resh \& Benavot, 2009; Kristiansen \& Pratikno, 2006; Galiani, Gertler, \& Schargrodsky, 2008 ; Faguet \& Sanchez, 2008; West \& Yloenen, 2010; Hanushek \& Woessmann, 2012; Carnoy, 2015; Hidalgo, 2015). Rather, I focus on why under the same political administration, concrete education policy decisions were made and soon reversed.

\section{Background}

\subsection{Overview of Political Developments in Georgia since the Rose Revolution}

Before introducing the details of education reform, a few words on the political context in Georgia when decentralization/recentralization policies were implemented are important. After the collapse of the Soviet Union, Georgia underwent a transition without democratization (Way \& Levitsky, 2010). President Shevardnadze, formerly Soviet Minister of Foreign Affairs, led the newly independent state until fraudulent parliamentary elections resulted in the Rose Revolution in 2003 (BBC, 2005). One of the leaders of the protests and the head of the United National Movement, Mikheil Saakashvili, was elected president with overwhelming support.

The revolution sparked hopes for a better future and was considered by many as a victory of democracy not only locally but internationally (Mitchell, 2004; Karumidze \& Wertsch, 2005; European Stability Initiative, 2010). New institutions were established that had the potential to become the basis of democratic governance. International organizations and the 'West' had largely positive assessments. For example, Georgia became a 'top performer" on the World Bank's Ease of Doing Business index (World Bank, 2006). Georgia's anti-corruption reform was praised for successfully eradicating petty corruption (Transparency International, 2013) and tax reform was seen as a remarkable improvement (Transparency International, 2010).

On the other hand, as time passed, some analysts used Georgia's example to illustrate how electoral revolutions have little effect in promoting democratization (Kalandadze \& Orenstein 2009; Tudoroiu, 2007; Hale, 2006). Freedom House warned that the 'West' was "too quick to declare democracy's success in Georgia" and pointed to the shallow roots of its new institutions, weak media and judiciary (Freedom House, 2014). Some argued that while Georgia was progressing in state-building it moved away from democracy (Lanskoy \& Areshidze, 2008; De Waal, 2011). Others argued Georgia was a competitive authoritarian regime (Way \& Levitsky, 2010; Tarkhan-Mouravi, 2011) where weak institutions, pseudo-liberal democracy and a troubled judiciary are disguised in democratic apparel.

Considering the abovementioned skepticism, some analysts maintained that despite the pitfalls, the overall progress that Saakashvili's government made with its major economic and political reforms made the country stand out as "frontrunner" in the South Caucasus region (Delcour \& Duhot, 2011, p. 43).

\subsection{Education Reform}

Following the Rose Revolution, all-encompassing education reforms passed. The revolutionary government inherited a legacy of corruption in the education system. The most notorious example of corruption was the university entrance exam, where parents engaged in bribery and other types of corrupt practices with those who administered the examinations at various universities (Janashia, 2004; Rostiashvili, 2004). Other problems in education included the misalignment of education system objectives, outdated teaching and learning standards, overloaded curriculum, inadequate learning materials, an inefficient management system, nontransparent distribution of resources, the low prestige of the teaching profession, and increasingly rare professional development opportunities (World Bank, 2001a; Kobakhidze, 2013).

Government officials stated in the media that the educational reform had to be founded on liberal and democratic values, and bring more transparency and justice to the system. Along with officials' rhetoric, the aims of the government were also expressed in legal documents, such as the National Goals of General Education (2004), Law of Georgia on General Education (2005) and Law of Georgia on Higher Education (2004). The Law on 
General Education reorganized schools based on the principles of democratic governance, transparency and school autonomy in financial and administrative matters.

Even though the 2007-2011 education strategy envisaged school governance decentralization as part of the reform (Ministry of Education and Science of Georgia, 2007), as time passed, educational practice and governance became inconsistent and contradicted earlier commitments. Policy action did not coincide with policy talk. The most obvious change was in the area of school autonomy and school governance decentralization. While some of the reform initiatives, including university entrance exams (Chankseliani, 2013) and the school funding formula (Janashia, 2015) that involved some type of centralization endured, the autonomy of school governance was reduced every year from 2007 to 2012, resulting in more centralized control.

The first amendments to the Law on General Education, leading to more centralization, emerged in 2008. From 2008 until 2011, the law was amended several times in order to give more control to the Ministry and less control and autonomy to the schools (Mshvenieradze, 2011).

State control became more stringent. The Ministry Inspectorate began to actively exercise its right to enter schools and ask for documents in order to verify whether school actions were in line with ministerial legal acts (Mshvenieradze, 2011). When School Boards did not comply with the Ministry in the name of autonomy (e.g. did not fire the principal as suggested by the Minister), the Ministry's inspection body would inspect the school (Netgazeti, 2011; Kevanishvili, 2011).

In 2010, the Ministry limited communication channels for schools. According to Ministerial Decree \#837 (Ministry of Education and Science of Georgia, 2010a), the schools needed special permission from the Ministry for any kind of cooperation with NGOs, the media, churches, political parties, etc. This permission was almost never granted. Following this policy, media reports critical of the education system with interviews from school community members became scarce.

The Ministry of Education and Science (MoES) introduced so-called "Mandatories" in 2010. Mandatories were school safety officers responsible for keeping law and order in the schools. Mandatories were hired and fired by an agency under the MoES and were accountable to the MoES. According to the new amendments to the Law on General Education (2005), Mandatories had important administrative powers. For example, they could supervise compliance with the school charter and attend the school and pedagogical board as well as the discipline and appellate committee meetings (Gorgodze, 2011). The introduction of this position (with three Mandatories in each school) ultimately led to decreased school autonomy and a reduction of teacher and principal powers (Gorgodze \& Janashia, 2012).

A new textbook policy deprived schools of the autonomy to choose textbooks. In 2011, a new system of textbook approval reduced the choice of textbooks dramatically. For example, while in 2010 there were nine textbooks approved for English Language, from a number of publishers (National Curriculum and Assessment Center, 2010), in 2011 there was only one publisher's textbook approved and schools had no choice but to use that particular textbook (Education Quality Enhancement Center, 2011). The new textbook approval scheme also envisaged that the state "automatically becomes co-owner of the approved textbook" and the state also was given the right to purchase the copyright and print the books themselves (Ministry of Education and Science, 2010b).

\section{Theoretical Framework}

To explain educational change in Georgia, I utilize two theories: The Multiple Streams model of decision-making (Kingdon, 1995) and the Electoral Connection theory (Mayhew, 1974). The Multiple Streams theory has been quite popular and used by many authors to explain educational policymaking, especially in the sphere of higher education (e.g. McLendon, 2003; Lieberman, 2002; Zahariadis, 2003; Holderness, 1992; Teodorovic, 2009; Ness, 2010).

While analyzing my findings through the lens of the Multiple Streams Model of decision-making, it became evident that the influence of the political stream in the country (particularly elections and electoral support) was paramount in reversing the policy of decentralization. Thus, the second theory, Electoral Connection, was chosen due to its focus on elections and the electorate. Even though the theory is focused on American politics and based on research on Congress and Congressmen's behavior, I was interested if the major tenets of the theory could be compatible with the political setting in Georgia.

\subsection{Multiple Streams}

Kingdon (1995) revised the Garbage Can Model (Cohen, March, \& Olsen, 1972) and proposed what is frequently referred to as Multiple Streams theory. The theory states that policy change takes place when 
problems, policies and politics streams are joined together. These streams are understood as distinct from one another, but the impetus for agenda or policy change is their coupling. When the three streams are joined together-for example, when a solution becomes coupled with a problem and is also supported in the political stream-it is very likely that the item will be placed "on the decision agenda" (p. 178).

In order to fully understand Multiple Streams theory, each stream should be defined. First, according to Kingdon, the problems stream highlights issues that become the focus of attention due to existing indicators that might assess the seriousness of the problem, focusing events (e.g. crises), and received feedback (Kingdon, 1995). Next, the policies stream includes area specialists, researchers, and interest group analysts who have an expertise in the particular policy sphere and express ideas in the policy community which float in what he calls "The Policy Primeval Soup". The ideas that survive meet certain criteria (e.g. technical feasibility, value acceptability, cost, chance of acceptability by politicians). Finally, the political stream is made up of national mood, public opinion, election outcomes, interest group campaigns, and ideological or partisan changes in congress. National mood does not necessarily reflect the mood of the masses, but rather "active sectors of the public" (p. 162).

The coupling of the three streams happens when a "policy window" emerges. This is most likely to happen as a result of events in the political stream (e.g. a new administration is put in place) or some crisis, and presents an opportunity when someone can push their proposals. Policy entrepreneurs work on preparing the environment for change and wait for the policy window to open. As discussed below, both school governance decentralization and recentralization relied on "policy windows" to be pushed on the decision agenda. Before exploring this further, I describe Electoral Connection theory.

\subsection{Electoral Connection Theory}

Mayhew's theory of Electoral Connection was primarily used to explain congressional behavior. It holds that the overarching interest motivating policymakers is reelection (Mayhew, 1974). Fenno (1978) also argues that among the three major goals that the congressman have, re-election is primary followed by power in Congress. The third goal, sound public policy, only becomes possible after the first interest is realized.

According to Electoral Connection theory, policymakers use advertising, position-taking and credit claiming to achieve re-election. Advertising is primarily used for name recognition. The more voters recognize a congressman, the greater are their chances of reelection. Credit claiming is when congressmen attempt to show a significant contribution to desirable government action. Position-taking is when a congressperson takes a stand/position on a particular issue and expresses it in the media, press releases or during campaigns (Mayhew, 1974). Notably, politicians are in a position where they can easily and legally engage in any of the three activities.

\section{Method}

Twenty-seven ( $\mathrm{N}=27)$ individual interviews were conducted with elites at different levels. The majority were top policymakers. For the purposes of this study I follow Dexter's (1970) definition of elite interviewee, which considers such an interviewee anyone "who in terms of the current purposes of the interviewer is given special, non-standardized treatment" (Dexter, 1970, p. 5). Thus, I do not differentiate between those having high political power and those who are considered experts but do not hold politically powerful positions like in some other definitions (Leech, 2002; Lilleker, 2003).

Interviewees were selected based on their personal involvement in and/or experience with educational policymaking. More than twenty of my interviewees were education policymakers, and they served in office at some point between 1998 and 2012. Interviewees included Ministers of the Ministry of Education and Science of Georgia and their deputies $(\mathrm{N}=12)$; two members of parliament $(\mathrm{N}=2)$; two representatives of international donor organizations with close ties to the Ministry and educational policymaking $(\mathrm{N}=2)$; six directors of semi-autonomous educational agencies $(\mathrm{N}=6)$ (Note 2); two education experts $(\mathrm{N}=2)$ and two former MoES employees $(\mathrm{N}=2)$ who either had power over policy-making at different times or were knowledgeable of policymaking processes. One former Minister of another Ministry $(\mathrm{N}=1)$ was later interviewed because interviewees claimed the individual had power over education-related decisions.

A semi-structured questionnaire was used to gather the information about: the most important decisions in the last ten years; the process of education policy formulation and decision making; factors influencing decision-making on school governance, decentralization and recentralization; critical moments in the reversal of decentralization policies; the main driver of changes and main participants in educational policymaking; the role of stakeholders/interest groups in decision-making; the extent of similarity in decision-making patterns in general education over the ten year period, among a number of other issues. Depending on the interviewee, 
questions differed slightly to accommodate the interviewee's professional role and expertise.

To enhance the credibility of interview findings, numerous legal documents, relevant research and assessment reports, and media sources were used both prior to conducting the interviews and after the analysis to double-check and confirm the elites' narratives provided.

My experience working at the Ministry of Education and Science from 2004 to 2010 should be noted. This connection can be viewed in two ways. On the one hand, this likely helped me secure interviews, and in fact none of the contacted interviewees declined the invitation to participate. It also enabled me to ask more detailed questions. On the other hand, I acknowledge my experience and relationship with some interviewees could have influenced their responses as well as the types of questions I put forward.

All but two interviews were conducted in person. For the two cases where the individuals lived outside the country, Skype video calls were used. Interviews lasted, on average, one hour and thirty minutes. Five of the interviewees were contacted after the data analysis stage for clarifications on previous interviews.

The data analysis process was bottom-up and inductive (Creswell, 1998; 2002). I read the transcripts and identified codes in each interview. Codes were classified into categories. The next step was to make sense of these categories and formulate them into major themes, some of which are developed in this article.

The interviewees were promised confidentiality. To ensure confidentiality, I do not attribute quotes to individual policymakers. This is of particular importance given many interviewees' highly public roles. However I differentiate between policymaker elites (Ministers of Education, Deputy Ministers, Cabinet Members, Agency Directors, Members of Parliament) and non-policymaker elites (donors/experts/ministry employees) and assign them relevant letters (PE or NE).

\section{Results}

\subsection{Decision on School Governance Decentralization}

The first finding is that decentralization of the school system was not included within the World Bank Education System Realignment and Strengthening Program (World Bank, 2001). This is significant because the program was the major reform framework within which the new government operated and many people believe that school decentralization was advocated for through this program. The interviewees reported that school governance decentralization was a decision which came from the central government and was later implemented with donor support.

However, a majority of the interviewees noted that the groundwork for the reform was in place. As one respondent pointed out (NE), in the 90s some international and non-governmental organizations in Georgia published research arguing that school autonomy and participatory governance would be effective for school improvement. In this period, international organizations were becoming more and more active in reforming the Georgian education system. A number of international organization reports support these claims (see: Open Society Institute, 2001; Council of Europe, 2000; UNESCO, 2000). At the end of 1998, the Georgian government had already signed an agreement with the World Bank for an education project preparation grant and in 2001 the first installment (US\$25.9 million) of the US\$60 million Education System Realignment and Strengthening Program in Georgia was approved (World Bank, 2001).

Many interviewees connected school governance decentralization to the general liberalization and democratization movement in the country. In this movement, civil society and western-educated individuals played a central role. In the words of one interviewee, "in the society and the political establishment, the demand to move from autocracy to democratic governance was ripe" (NE). As the interviewee explained, public dissatisfaction grew amidst the economic difficulties, widespread corruption and autocratic style of governance.

The respondents were unanimous in reporting that the Rose Revolution provided an impetus for the introduction of a wide array of reforms in the Georgian education system. One policymaker stated:

This was a historic moment for our country to make changes. Our team had a high level of political support and in a few years we knew we could see that this support would not be so powerful, because the National Movement [party] would accumulate mistakes and on the other hand the people would have a diminished drive for change (PE).

Many respondents agreed that the decentralization of school governance became a "pillar stone" (PE) of education reform. According to one policymaker, there were two major aims to education reform: empowerment through delegation of governance powers to schools and redefinition of the function of the education system. S/he stated, "I think the struggle for survival from 1992 almost up to the Rose Revolution in 2003 made the 
school and the university forget what they were for, so we wanted to redefine this. These two approaches were expressed in institutional, financial, conceptual and management frameworks followed by the content" (PE).

When asked whether school governance decentralization decisions were hard to make as they involved such radical changes, all of the interviewees pointed to the high level of public support that gave politicians the green light to take even the most risky and unpopular decisions.

Interviewees agreed that the major domains of education reform were introduced in a fast-paced manner and without much piloting. One respondent explained that even though the government expected implementation problems, they wanted to work through these problems while there was still strong public support (PE).

\subsection{Implementation of School Governance Decentralization}

A number of interviewees noted that the implementation of decentralization reform was sometimes rocky. Interviewees named the following implementation challenges: the school communities were not ready for radical change; school capacity for the new model of governance was insufficient; the new per capita funding formula left many schools with scant finances and there were no resources for the school boards to exercise financial autonomy; and principal elections with new regulations created some problems. These narratives are in line with previous research which has highlighted similar problems (Apkhazava \& Bregvadze, 2008; Herczynski \& Durglishvili, 2011; Janashia, 2015; Janashia \& Gorgodze, 2013).

Some interviewees reported that the period when schools were allowed to be autonomous was too short to internalize autonomy and independent decision-making. Because of this, a very small number of schools were able to use the autonomy wisely - that is to the benefit of their schools.

One of our respondents pointed to the fact that schools were afraid to act autonomously, because practice was different from rhetoric, and when schools had to take care of a small issue they still had to seek approval from the central government. S/he stated:

How can we talk about democratic and decentralized institutions when most governmental organizations still have ODR in their staff? (Note 3). Many autocratic methods from old times were in fact preserved and are preserved to this day (NE).

Research conducted on school system decentralization (Caucasus Institute for Peace, Democracy and Development, 2009) found that while attitudes towards decentralization were positive, the majority of School Boards were managed by the principal and acted under the principal's control, not realizing that the education law allowed them to sack the principal if they did not like him or her. Notably, the research showed that despite the new regulations that gave schools autonomy, the principal was under the influence of the Ministry of Education.

\subsection{Decision on School Governance Recentralization}

After a few years of school governance decentralization, the government decided to reverse the decentralization process in favor of centralization. When asked why this happened, a majority of respondents cited the government's need for control over schools given their dwindling public support and the upcoming elections. Respondents also cited the "shallow roots" (NE) of the decentralization reform, inexperience of the government, the fear of losing power, and territorial conflict in the country as reasons for the reversal. Notably, one respondent (PE) connected decentralization with chaos in the schools, which they claimed was caused by the lack of political culture and detailed regulations. S/he thought that this in turn necessitated the recentralization reform.

Both policymakers and other elites agreed that the government started reconsidering its radical decentralization reform starting in 2007. Interviewees mentioned shaken public support, a lack of stability in the country, and the upcoming elections as influential factors in narrowing the window of autonomy.

One policymaker explained that after the demonstrations in November 2007, when the president resigned and the country held extraordinary elections, the president and the governing party realized that decentralized school system would not guarantee electoral success (PE). Another respondent made remarks along similar lines:

Then they [revolutionary government] were in euphoria and thought that everyone would vote for them. But, as the time for the first elections approached, they realized this was not the case and panicked...So this decentralization and educational quality thing were all a small period of euphoria (NE).

Several policymakers emphasized the role of regional governors in creating the impression that school governance decentralization undermined electoral success. Respondents suggested that the reason for this was 
their dissatisfaction, because governors could not involve themselves in school issues within the school governance decentralization's framework. Consequently, local governors would not be able to mobilize support in local elections through the schools (as occurred in previous decades), since, in the name of autonomy, schools could legitimately reject governor directives.

Even the policymakers who did not want to undermine the former government's concern for education quality emphasized the importance of electoral goals. As one respondent explained, it was impossible to ignore the role of schools in elections given that schools serve as polling places and teachers and principals are often involved in the election administration (PE).

One policymaker explained that the government's measures were not directed against the process of decentralization per se, but against the inability to control schools, which in turn lead to political problems (PE). Most interviewees also noted that politicians' use of the schools to gain public support appeared natural in Georgia:

When the resources of the country's regions' are discussed, you always think of a teacher who is in every village and is, so to say, a 'qualified resource'... You do not want the election process to fail simply, because for example, a particular teacher or principal is motivated to do so (PE).

Another respondent stated that government officials believed they could influence teachers' votes through school principals, and teachers could influence their students and even students' families. S/he stated, "these schemes worked in Georgia in the times when the opposition was weak and even absent (from 1995 to 2003), and votes were needed to preserve the country's democratic face for the international community (NE)".

Several respondents connected the need for centralization to security concerns. The territorial conflict in South Ossetia in 2008 resulted in significant problems, with additional internally displaced people to shelter and a stronger threat to state sovereignty. According to these respondents, more control over schools and expanded security measures were necessary so that external forces did not exploit school autonomy. As one respondent noted, even those with liberal values would say "now the major goal is safety in the country and democracy can wait a little (PE)."

\subsubsection{Credit-Claiming, Populism, and Political Hiring and Dismissal Decisions}

The interviews point to the fact that the government started thinking about getting credit for the reforms, starting in 2008. This was important, because the government realized it needed to accumulate credit for the upcoming elections. As one respondent stated:

This model [of school governance] was a radically different model compared to what we had before. So it needed large effort to make the public a) believe that this would work [and] b) empower them to act so that it worked. And elections were approaching....public resistance and nihilism could not be overcome, so the government saw they would not get credit for this reform (NE).

Contrary to the anti-corruption reform in education, where the government received credit, with regard to school governance decentralization, the success, if any, was ascribed to schools. However, for the failures, schools were quick to associate the decentralization policies with the government. As one respondent remarked, schools started using their freedom against the government and came out to protest things (PE).

Many respondents agreed that after 2007, populism and populist decision-making gained strength. As one respondent noted, the government decided that "instead of going on with the school governance decentralization reform at all costs, it was wiser to think about the costs [costs and benefits of reform]" (PE). The government decided to try to appease the electorate. If the public disapproved of something, the government's position was to concede and take the side of the majority.

When the government engaged in populism, some decisions undermined the school governance decentralization reform and strengthened both centralization and electoral prospects for the governing party. For example, when the government increased teacher salaries, they did not provide a proportional increase in per capita funding to schools, leaving much less funding for schools self-governance (PE).

Many respondents connected the presidential elections with increased control and election-related hiring and dismissal decisions. School principals, Education Resource Centers (Note 4), and teachers alike were to assist the ruling party in getting re-elected. One respondent said that "there emerged the feeling that the educational system needs centralization. It needs people in education to be screened and to be checked for who is a supporter of the National Movement [party] and who is not (PE)."

Another respondent noted the job insecurity of Educational Resource Center staff during this period. S/he 
mentioned that as many as nine ERCs heads (approximately 13\%) were replaced after the elections in 2008, and the main reason for their dismissal was either that the municipality lost the elections or because they took leave during elections and did not assist in the election process (NE).

\subsubsection{Tighter Control, Advertising and Intimidation}

Interviewees reported that after 2010, control of schools intensified. One respondent noted, "When the political situation did not stabilize, the government decided to take stricter measures to increase control and decrease autonomy" (PE). Several respondents suggested that the majority of decisions came from the president or the Ministry of Internal Affairs. Others named approximately five people who had power over decisions but respondents were not unanimous about a certain individual who would be considered a "policy entrepreneur".

One respondent reported that if earlier Ministry staff and education officials were asked their opinions about perspective policies, in the period starting in 2008-2009 policy decisions came from above. "We had to agree to some decisions with people who had no connection whatsoever to education. My thinking is that the situation inside the political team was also tense and some security forces had some information that was important to consider in policymaking (PE)."

Many respondents agreed that the advertising and public relations (PR) component of education policy became very important. Education research was ignored and discouraged, and Georgia withdrew from international assessments. The mass media and especially television was used to show that the country's education system was on the right track. Stories that the government considered 'success stories' were televised and popularized. As one policymaker noted about the importance of PR in 2010:

Not only in education but in other spheres a lot of ribbon cutting ceremonies were televised every day...sometimes buildings were not finished and on TV we saw the president was cutting the ribbons of unfinished constructions (NE).

In addition, the Mandatories (school safety officers) received wide media coverage, and public service announcements highlighted the Mandatories' positive features. It is interesting that only three months after its introduction, the Ministry of Education and Science claimed that they had conducted research (that is not publicly available to date) according to which school safety dramatically improved after Mandatories were introduced into schools (Ministry of Education and Science, 2010c).

Social networks were carefully monitored. Several respondents noted that some hiring and dismissal decisions were connected to social network activities. One respondent shared how s/he had to fire a staffer "because apparently s/he openly voiced dissatisfaction with the government's actions on Facebook (PE)."

The interviews revealed that from 2010 on, schools and particularly principals and teachers felt more and more intimidated. They were afraid to voice any type of criticism towards official education policy in the media. The frequent and often ill-founded firings of teachers, ERC heads, and principals sent a message demanding obedience to school community members. One respondent said that teacher firings received "very weak coverage in the media and very little opposition from teacher unions or other stakeholders. So, the message was clear for other teachers (NE)."

Another respondent referred to governance during this period as "oral governance"(PE), referring to the informal directives that appeared to be stronger than formal ones. For instance, a number of press reports show that oral directives from the Ministry of Education and Sciences led to teacher firings (Mtivlishvili, 2010). Many respondents regarded mandatories as a control mechanism in schools. Mandatories had higher salaries than teachers and were accountable directly to the Ministry of Education and Science. As one respondent stated:

While, on the one hand, some things were corrected with their entrance to schools (e.g., truancy decreased), it was clear that teachers and principals were subordinate and regarded the Mandatories as representatives of the Ministry (PE).

One study conducted with 300 families (Andguladze, Mosiashvili, \& Kechakmadze, 2012) shows that school communities thought mandatories had even greater powers than they had de jure (Note 5). The authors found that $47 \%$ of students believed that Mandatories could kick them out of school; $63 \%$ believed they could search the student; and $35 \%$ thought they could fire teachers.

A couple of respondents regretfully remarked that all this control resembled the Soviet Union. One respondent added that "our society and its governance consequently is still far from Western values and it easily drifted in the wrong direction (PE)." However, most respondents were unanimous in believing that, despite all the restrictions and control, you simply cannot compare the two scenarios. As one policymaker stated: 
During the Soviet Union, even the concept of school autonomy was nonexistent...Now, the school is still more or less autonomous, but the state tries to have additional leverage to have influence and power over the schools. The major institutional mechanisms are still functioning (PE).

\section{Discussion}

When examined through the lens of two theoretical frameworks, data analysis reveals that the Multiple Streams model of decision-making has some explanatory power both for the decentralization and recentralization decisions. While the theory of Electoral Connection does not explain the decentralization decision, it has strong explanatory power for the decisions concerning school governance recentralization, and the evidence suggests that decisions about recentralization were election-driven (motivated by the desire to improve electoral prospects).

As the interviews and case narrative illustrates, school governance decentralization became possible as the three streams of problems, policies and politics were joined together during a focusing event-a revolution following flawed elections. However, the model is slightly modified to match the case. Specifically, I argue that after the three streams come together during a focusing event, what follows is not the decision but rather a change in one of the streams as a pre-requisite to the subsequent decision on policy change. As depicted in the model below (Figure 1), the political stream changes radically after the policy window is opened and this is the primary factor in the resulting policy change in education, rather than the coupling of the three streams alone.

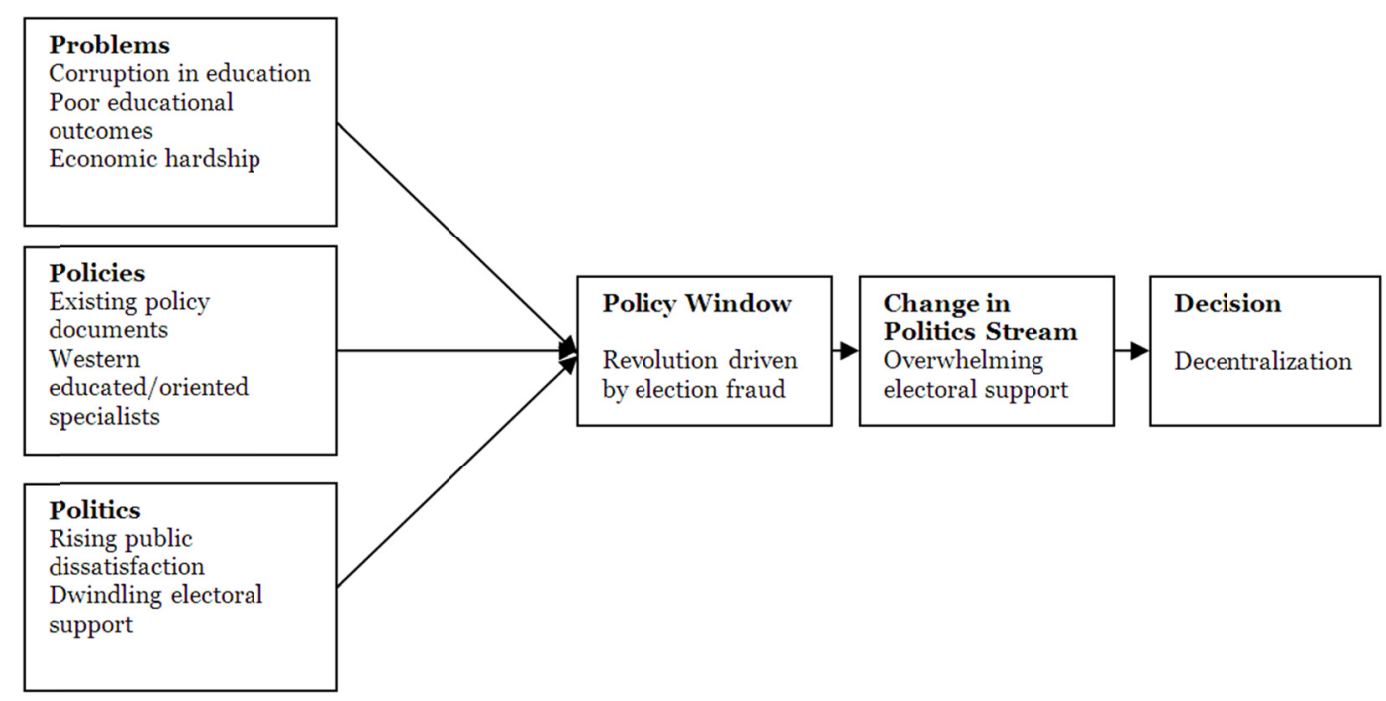

Figure 1. Multiple Streams Model of school governance decentralization

A policy entrepreneur, that is an organization or individual who invests much of his/her/its time and energy into pushing a certain idea on a decision agenda, was not identified in the research. While Kingdon (1995) suggests the policy entrepreneur is a necessary element in the Multiple Streams Model, someone who softens up the situation and lays the groundwork for a decision, in our case, the respondents were not unanimous about a single individual/organization, which was a policy entrepreneur. However, respondents could list five or more people who would have been supporting the initiative. The policy entrepreneur, in the present case, seems to be a number of individuals both in the decentralization and recentralization processes. 


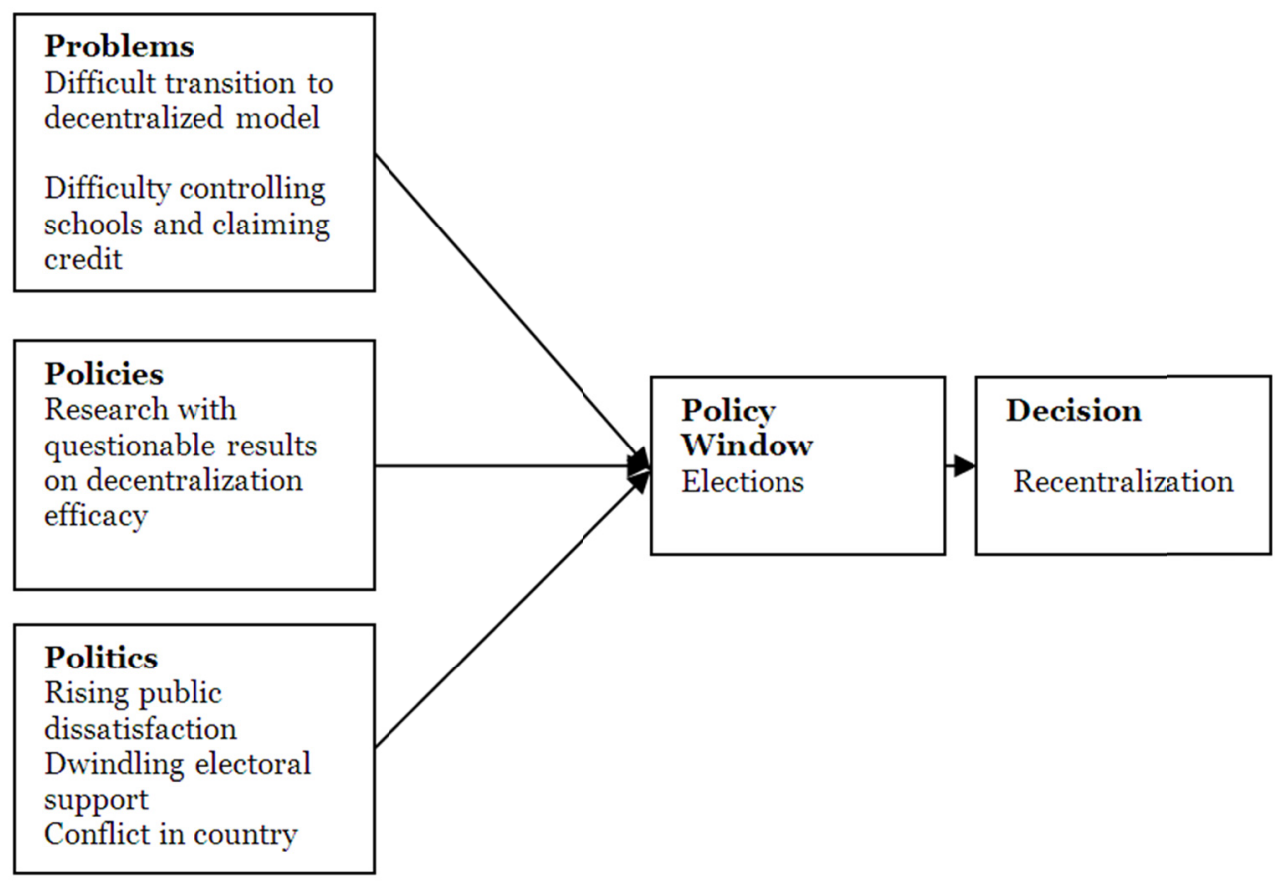

Figure 2. Multiple Streams Model of school management recentralization

As for the recentralization decision, the Multiple Streams model explains the case without the modification mentioned above, as the change in the politics stream did not take place after the policy window emerged.

As seen above, both in the case of decentralization and recentralization, there is a strong focus on elections under the "political stream". This was the primary reason to use the Electoral Connection theory to better explain the connection of decision-making in education to the elections.

The findings show that the theory has little explanatory power when there is significant electoral support. In other words, when the government came to power through an overwhelming electoral victory in 2003, it was ready to take unpopular decisions without any fear of irritating the public and undermining its support. The Electoral Connection theory only applies when there is a certain condition: decreasing electoral support. In such circumstances the findings show that the primary motivator behind decisions is to retain power i.e., to be reelected. In the government's view, being re-elected was primary, because they would not have been able to pursue other good policies in education.

The interviews allowed me to look into the tools of retaining support described in Electoral Connection Theory. In the Georgian recentralization case, electoral support is realized not only by three important activities (advertising, credit claiming, position-taking), but through other methods as well.

When electoral support shows the first signs of decline, the tenets of the Electoral Connection theory apply. In other words, use of advertising, credit-claiming and position-taking (in this case I identify position-taking with populism) become important when there is a threat of losing power. However, when electoral support is seriously threatened, the abovementioned three tools are also supplemented with other activities. These activities can be boiled down to three tools that are forms of Electoral Control rather than Connection:

Pressure: implicit intimidation, insecurity in employment, intolerance of criticism of those in power;

Political Appointments: employment decisions largely based on political loyalty;

Control-based Governance: closure of the system, no delegation of powers, top-down micromanagement.

The government devotes substantial resources to the abovementioned activities, and their level of use depends on the severity of public dissatisfaction and political crisis in the country.

Using two theoretical frameworks and a qualitative study design, I conclude that my case mostly supports the Multiple Streams Model of decision-making, as educational change occurred when the three streams-problems, policies and politics-joined together during a focusing event. However, I try to extend the theory by arguing that 
in the decentralization case the coupling of the three streams transformed the political stream, and this is what caused educational change.

The theory of Electoral Connection applies only when there is decreasing electoral support. When electoral support is extremely high, our findings indicate that decisions made in education are directed at improving the education sector. When electoral support declines decision-making can be electorally driven, even if the same political administration is in power. This is when electoral connection theory becomes important. The Georgian case also extends the theory of Electoral Connection. I argue that when electoral support is particularly troublesome, electoral connection and election-driven decision-making grows into Electoral Control expressed in control-based management, pressure and political appointment.

\section{Conclusion}

This research examined educational decision-making practices in a post-soviet country, Georgia, in order to gain greater insight on the forces shaping educational change in the transition from a soviet past to a democratic future. Focus was placed on school governance decision-making, and the specific reasons that a concrete decentralization decision was made and soon reversed even though the same political administration remained in office.

The findings contribute to the existing literature on policymaking in post-soviet countries which primarily focus on the role of policy borrowing and policy transfers in educational decisions. The case demonstrates that there are other important factors that may reverse decision-making processes, such as elections. This finding can be useful for investigating decision-making in other newly democratized states. Moreover, further research should investigate the role of elections in education policy decision-making.

Further research on the Georgian case would also be significant considering that in the parliamentary elections of 2012, the United National Movement lost the elections and President Saakashvili conceded his party's defeat. Despite the fact that centralized school governance did not help in electoral victory (for the first time in Georgia's history), the legal framework and amendments to the Law on General Education that reduced school autonomy are still intact, with one notable exception. Mandatories no longer have a "control" function.

To date, anecdotal evidence suggests multiple issues have arisen (e.g. in terms of school autonomy, principal elections, textbooks, teacher selection, etc.) that indicate the government favors centralized school governance. Research on these and similar issues could answer whether the practice of control in education still prevails or whether the Republic of Georgia has outgrown the perception that greater control of school governance means more votes and more power.

\section{Acknowledgements}

This work was supported by the Central Asia and Caucasus Research and Training Initiative.

I would like to thank Prof. Gigi Tevzadze, Prof. Val Rust, Dr. Simon Janashia, Dr. Anne Campbell and Prof. Giorgi Gakheladze for their advice and critical perspective at different stages of research and writing. I would also like to thank every interviewee who agreed to be my respondent despite their busy schedules and responsible positions.

\section{References}

Abkhazava, R., \& Bregvadze, T. (2008). Assessment of decentralization reform. International Institute for Educational Planning and Management. from http://www.apkhazava.gol.ge/EPPM/angarshi\%20decentr.pdf

Andguladze, N., Mosiashvili, T., \& Kechakmadze, V. (2012). Safe school policy in Georgia: Prerequisites, outcomes and attitudes. In Student Centered School Guide. Retrieved from http://dspace.nplg.gov.ge/handle/1234/4350

BBC. (2005, May 10). How the Rose Revolution Happened. Retrieved from http://news.bbc.co.uk/2/hi/4532539.stm

Carnoy M., \& Hannaway, J. (Eds.). (1993). Decentralization and school improvement: Can we fulfill the promise? San Francisco, CA: Jossey-Bass.

Carnoy, M. (2015). Four keys to Cuba's provision of high-quality public wducation. Presentation delivered at Comparative and International Education Society conference 2015. Washington DC.

Caucasus Institute of Peace, Democracy and Development. (2009). Assessment of current education reform. Retrieved from http://www.nplg.gov.ge/gsdl/cgi-bin/library.exe?e=d-00000-00---off-0civil2-civil2-01-1--0- 
10-0--0-0---0prompt-10--.\%2e-4----4---0-01--11-ka-10---10-help-50--00-3-1-00-0-00-11-1-0utfZz-8-10-0-1 1-1-0utfZz-8-10\&a $=\mathrm{d} \& \mathrm{c}=$ civil2\& $\mathrm{cl}=\mathrm{CL} 1.11 .4 .1 \& \mathrm{~d}=\mathrm{HASHb} 476 \mathrm{ff} 77 \mathrm{~d} 12749 \mathrm{ec} 67 \mathrm{f3} 4 \mathrm{~b} .4 .7$

Chankseliani, M. (2013). Higher education access in post-Soviet Georgia: Overcoming a legacy of corruption. In H. Meyer, E. P. John, M. Chankseliani, \& L. Uribe (Eds.), Fairness in access to higher education in a global perspective: Reconciling excellence, efficiency, and justice (pp. 171-187). http://dx.doi.org/10.1007/978-94-6209-230-3_10

Cohen, M. D., March J. G., \& Olsen J. P. (1972). A garbage can model of organizational change. Administrative Science Quarterly, 17(1), 1-25. http://dx.doi.org/10.2307/2392088

Council of Europe. (2000). Activities for the development and consolidation of democratic stability. Retrieved from http://www.coe.int/t/dg4/education/historyteaching/Source/Cooperation/TbilisiInitiative/TbilisiDeclara tion2000_en.pdf

Creswell, J. W. (1998). Qualitative inquiry and research design: Choosing among five traditions. Thousand Oaks, CA: Sage.

Creswell, J. W. (2002). Educational research: Planning, conducting, and evaluating quantitative and qualitative research. Upper Saddle River, NJ: Pearson Education.

De Waal, T. (2011). Georgia's Choices: Charting a future in uncertain times. Washington DC, VA: Carnegie Endowment.

Delcour, L., \& Duhot, H. (2011). Bringing South Caucasus closer to Europe? Achievements and challenges in ENP implementation. College of Europe Natolin Research Paper No. 2011/3. Retrieved from http://ssrn.com/abstract=1923753

Dexter, L. (1970). Elite and specialized interviewing. Evanston, Ill: Northwestern University Press.

Education Quality Enhancement Center. (2011). List of approved books. Retrieved from http://old.eqe.ge/geo/textbook_approval/approved_textbooks_2011

European Stability Initiative. (2010). Georgia's libertarian revolution. Part one: Georgia as a model. Retrieved from http://www.esiweb.org/pdf/esi_-_georgias_libertarian_revolution_-_part_one_-_georgia_as_a_model_ -_10_april_2010.pdf

Faguet, J., \& Sánchez, F. (2008). Decentralization's effects on educational outcomes in Bolivia and Colombia. World Development, 36(7), 1294-1316. http://dx.doi.org/10.1016/j.worlddev.2007.06.021

Fenno, R. F. (1978). Home style: House members in their districts. Boston, MA: Little Brown.

Galiani, S., Gertler P., \& Schargrodsky, E. (2008). School decentralization: Helping the good get better, but leaving the poor behind. Journal of Public Economics, 92(10-11), 2106-20. http://dx.doi.org/10.1016/j.jpubeco.2008.05.004

Georgia General Education Decentralization and Accreditation Project (GEDA). (2006). Retrieved from http://www.equip123.net/webarticles/anmviewer.asp?a=435

Gorgodze, S. (2011). Safe school and international experience. In Safe school without community involvement. Civic Development Institute. Retrieved from http://dspace.nplg.gov.ge/handle/1234/9949?mode=full

Gorgodze, S., \& Janashia, S. (2012). Policy note on safe school. In Student centered school guide. Retrieved from http://dspace.nplg.gov.ge/handle/1234/4350

Government of Georgia. (2004). National goals on general education. Tbilisi, Georgia.

Government of Georgia. (2005). Decree \# 75. Tbilisi, Georgia.

Hale, H. E. (2006). Democracy or autocracy on the march? The colored revolutions as normal dynamics of patronal presidentialism. Communist and Post-Communist Studies, 39(3), 305-329. http://dx.doi.org/10.1016/j.postcomstud.2006.06.006

Hanson, M. (1997). Educational decentralization: Issues and challenges. Retrieved from http://www.thedialogue.org/PublicationFiles/PREAL\%209-English.pdf

Hanson, M. (2000). Democratization and educational decentralization in Spain. A twenty year struggle for reform. Education Reform and Management Publication Series, 1(3). Retrieved from http://siteresources.worldbank.org/EDUCATION/Resources/278200-1099079877269/547664-10990800268 26/Democratization_and_ed_decentraliz_Spain_En00.pdf 
Hanushek, E. A., Link, S., \& Woessmann, L. (2012). Does school autonomy make sense everywhere? Panel estimates from PISA. Discussion Paper No. 6185. http://dx.doi.org/10.3386/w17591

Hidalgo, A. (2015). Chile's long-term neoliberalism experiment and its impact on educational quality and equity. Presentation delivered at Comparative and International Education Society conference 2015. Washington DC.

Holderness, S. T. (1992). The politics of state educational policymaking: The usefulness of the Kingdon model. In F. C. Wendel (Ed.), Issues of Professional Preparation and Practice (pp. 17-31). University Council for Educational Administration. University Park, PA: The Pennsylvania State University.

Interpressnews. (2013, October 17). Bidzina Ivanishvili: We are trying to say no to ODR institute. Retrieved from http://www.interpressnews.ge/ge/politika/256560?ar=A

Janashia, N. (2004). Corruption and higher education in Georgia. Boston College: Center for International Higher Education. Retrieved from http://www.bc.edu/bc_org/avp/soe/cihe/newsletter/News34/text006.html

Janashia, S. (2015). Introduction of per-capita education financing in former USSR countries (PhD dissertation, Teachers College, Columbia University).

Janashia, S., \& Gorgodze, S. (2013). Policy note on decentralization of general education system. In Decentralization of General Education System. Civic Development Institute, Tbilisi.

Kalandadze, K., \& Orenstein, M. (2009). Electoral protests and democratization: Beyond the color revolutions. Comparative Political Studies, 42(11), 1403-1425. http://dx.doi.org/10.1177/0010414009332131

Karumidze, Z., \& Wertsch, J. V. (Eds.). (2005). Enough! The Rose Revolution in the Republic of Georgia 2003. New York, NY: Nova Science Publishers,

Kevanishvili, E. (Reporter). (2011, June 21). General inspectorate to inspect schools. Radio Free Europe. Retrieved from http://www.radiotavisupleba.ge/content/article/24241597.html

Kingdon, J. (1995). Agendas, alternatives, and public policies. New York, NY: Longman.

Kobakhidze, M. N. (2013). Teacher certification examinations in Georgia: Outcomes and policy implications. http://dx.doi.org/10.1108/s1479-3679(2013)0000019007

Kristiansen, S., \& Pratikno. (2006). Decentralising education in Indonesia. International Journal of Educational Development, 26(5), 513-531. http://dx.doi.org/10.1016/j.ijedudev.2005.12.003

Lanskoy M., \& Areshidze, G. (2008). Georgia's year of turmoil. Journal of Democracy, 19(4), 154-167. http://dx.doi.org/10.1353/jod.0.0034

Leech, B. L. (2002). Interview methods in political science. Political Science and Politics, 35(4), 663-64. http://dx.doi.org/10.1017/S1049096502001117

Lieberman, J. M. (2002). Three streams and four policy entrepreneurs converge: A policy window opens. Education and Urban Society, 34(4), 438-450. http://dx.doi.org/10.1177/00124502034004003

Lilleker, D. (2003). Doing politics, interviewing the political elite: Navigating a potential minefield. Politics, 23(3), 207-14. http://dx.doi.org/10.1111/1467-9256.00198

Mayhew, D. R. (1974). Congress: The Electoral Connection. New Haven: Yale University Press.

McGinn, N., \& Welsh, T. (1999). Decentralization of education: Why, when, what and how? UNESCO. Retrieved from http://unesdoc.unesco.org/images/0012/001202/120275e.pdf

McLendon, M. K. (2003). Setting the governmental agenda for state decentralization of higher education. Journal of Higher Education, 74(5), 479-516. http://dx.doi.org/10.1353/jhe.2003.0038

Ministry of Education and Science of Georgia. (2006). The Ministerial Decree \#31. Retrieved from https://matsne.gov.ge/ka/document/view/62632

Ministry of Education and Science of Georgia. (2007). Consolidated education strategy and action plan (2007-2011). Tbilisi, Georgia.

Ministry of Education and Science of Georgia. (2010a). The Ministerial Decree \#837. Tbilisi, Georgia.

Ministry of Education and Science of Georgia. (2010b). The textbook approval rule changes. Retrieved from www.mes.gov.ge/content.php?id= $1603 \&$ lang $=$ geo

Ministry of Education and Science of Georgia. (2010c). The Cases of Violence Reduced. Retrieved from 
http://www.mes.gov.ge/content.php?id=1636\&lang=geo

Mitchell, L. (2004). Georgia’s Rose Revolution. Current History. A Journal of Contemporary World Affairs, 103, (675), 342-353.

Mshvenieradze, G. (2011). Safe school and Georgian legislation. Road from decentralization to centralization. In Safe School without Community Involvement. Civic Development Institute. Retrieved from http://dspace.nplg.gov.ge/handle/1234/9949?mode=full

Mtivlishvili, G. (Reporter). (2010, August 17). Minister fires you, not me. Retrieved from http://www.humanrights.ge/old/rss/index.php?a=more\&r=analytical\&id=5348\&lang=ge

National Curriculum and Assessment Center. (2010). List of approved books chosen by Georgian schools by subject and grade. Retrieved from http://ganatleba.org/index.php? $\mathrm{m}=95 \&$ newsid $=174$

Ness, E. (2010). The Politics of determining merit aid eligibility criteria: An analysis of the policy process. Journal of Higher Education, 81(1), 33-60. http://dx.doi.org/10.1353/jhe.0.0080

Netgazeti.ge. (2011, June 21). General inspectorate in schools. Retrieved from http://www.netgazeti.ge/GE/62/News/5468/

Open Society Institute. (2001). Open society-Georgia foundation: Annual report 2001. Retrieved from http://www.osgf.ge/files/wliuri_angarishi/Annual_Report_2001_Eng_ZESPc7iaks.pdf

Parliament of Georgia. (1999). Law of Georgia on legal entities of public law. Tbilisi, Georgia.

Parliament of Georgia. (2004). Law of Georgia on higher education. Tbilisi, Georgia.

Parliament of Georgia. (2005). Law of Georgia on general education. Tbilisi, Georgia.

Philips, D., \& Ochs K. (2003). Processes of policy borrowing in education: Some explanatory and analytical devices. Comparative Education Volume, 39(4), 451-461. http://dx.doi.org/10.1080/0305006032000162020

Resh, N., \& Benavot, A. (2009). Educational governance, school autonomy, and curriculum implementation: diversity and uniformity in knowledge offerings to Israeli pupils. Journal of Curriculum Studies, 41(1), 67-92. http://dx.doi.org/10.1080/00220270802446826

Rivera, W. S. (2004). Elites and diffusion of foreign models in Russia. Political Studies, 52(1), $43-62$. http://dx.doi.org/10.1111/j.1467-9248.2004.00463.x

Rostiashvili, K. (2004). Corruption in the higher education system of Georgia. American University's Transnational Crime and Corruption Center Georgia Office. Starr Foundation and IREX, Tbilisi.

Rudman, H. C. (1964). Structure and decision-making in Soviet Education. Studies in Comparative Education Series. Retrieved from http://eric.ed.gov/?id=ED053021

Shapiro, M., Nakata, S., Chakhaia L., Zhvania, E., Babunashvili, G., \& Tskhomelidze, N. (2007). Evaluation of the Ilia Chavchavadze Program in Reforming and Strengthening Georgia's Schools. Retrieved from http:/www.mes.gov.ge/upload/multi/geo/1209037866_IC\%20Evaluation\%20Report\%202007\%20Final.pdf

Silova, I. (2009). Varieties of educational transformation: The post-socialist states of Central/Southeastern Europe and the former Soviet Union. In R. Cowen, \& A. Kazamias (Eds.), International handbook of comparative education (pp. 295-320). http://dx.doi.org/10.1007/978-1-4020-6403-6_19

Silova, I. (2012). Contested meanings of educational borrowing. In G. Steiner-Khamsi, \& F. Waldow (Eds.), World Yearbook of Education 2012: Policy borrowing and lending in education (pp. 229-245). New York: Routledge.

Steiner-Khamsi, G. (2005). The economics of policy borrowing and lending: A study of late adopters. Oxford Review of Education, 32(5), 665-678; http://dx.doi.org/10.1080/03054980600976353

Steiner-Khamsi, G., Silova, I., \& Johnson, E. M. (2006). Neoliberalism liberally applied: educational policy borrowing in Central Asia. In J. Ozga, T. Seddon, \& T. Popkewitz (Eds.), World Yearbook of Education 2006: Education, research and policy: Steering the knowledge-based economy (pp 217-245). New York, NY: Routledge.

Tarkhan-Mouravi, G. (2011). Georgia's political experience after the Rose Revolution and some lessons that need to be learned. In P. O’Grady, \& L. Najšlová (Eds.), Democracy Delayed-Obstacles in Political Transition. Democracy Reporting International and EUROPEUM, 17-19.

Teodorovic, J. (2008). Why education policies fail: Multiple streams model of policymaking. Zbornik Instituta 
Za Pedagogska Istrazivanja, 40(1), 22-36. http://dx.doi.org/10.2298/ZIPI0801022T

Transparency international Georgia. (2010). Georgian taxation system. Retrieved from http://ransparency.ge/sites/default/files/post_attachments/Taxation\%20in\%20Georgia\%20_ENG_final_0.pd $\mathrm{f}$

Tudoroiu, T. (2007). Rose, orange and tulip: The failed post-Soviet revolutions. Communist and Post-Communist Studies, 40(3), 315-342. http://dx.doi.org/10.1016/j.postcomstud.2007.06.005

UNESCO. (2000). The EFA 2000 Assessments: Country reports-Georgia. Retrieved from http:/www.unesco.org/education/wef/countryreports/georgia/rapport_1.html

Way, L. A., \& Levitsky, S. (2010). Competitive Authoritarianism: Hybrid Regimes After the Cold War. Cambridge University Press.

West, A., \& Yloenen, A. (2010). Market-oriented school reform in England and Finland: School choice, finance and governance. Educational Studies, 36(1), 1-12. http://dx.doi.org/10.1080/03055690902880307

World Bank. (2001). Georgia Education Realignment \& Strengthening Program (APL\#1). Retrieved from http://www.worldbank.org/projects/P055173/education-system-realignment-strengthening-program-apl-1?1 ang=en

World Bank. (2006). Doing Business 2007: How to Reform. Washington D.C.

Zahariadis, N. (2003). Ambiguity and Choice in Public Policy: Political Decision Making in Modern Democracies. Washington: Georgetown University Press.

\section{Notes}

Note 1. Legal entity of public law is an entity created by the state, under the state control, but separated from it and independently implementing political, social, educational or other public activities (Law of Georgia on Legal Entity of Public Law, 1999).

Note 2. These agencies represented legal entities of public law under the Ministry of Education and Science of Georgia and were established in order to detach the content-related issues from the Ministry and ensure better quality. Agencies included the National Examination Center, National Curriculum and Assessment Center, Teacher Professional Development Center, and National Accreditation Center among others.

Note 3. ODR is Russian slang and means a specially tasked officer from the Ministry of Internal Affairs (MIA) who is implanted in other governmental institutions as part of the staff of the institution. The ODR is responsible for sending confidential information to the MIA. The Prime Minister of Georgia admitted that ODRs are still present in Georgian government offices in 2013 , when he publicly announced that they "try to say no to so called ODR institution and will probably manage in the near future" (Interpressnews, 2013).

Note 4. Educational Resource Centers represent local representative bodies of MoES. Originally they were aimed at supporting the school governance decentralization process (Georgia General Education Decentralization and Accreditation Project, 2006). They were meant to facilitate rather than control school activities by increasing their capacity through data collection and research, training and workshops, etc. (Ministry of Education and Science, 2006)

Note 5. Research was conducted outside of schools because as authors state, research team did not receive a permission from the Ministry to conduct research in schools.

\section{Copyrights}

Copyright for this article is retained by the author(s), with first publication rights granted to the journal.

This is an open-access article distributed under the terms and conditions of the Creative Commons Attribution license (http://creativecommons.org/licenses/by/4.0/). 